\section{Regional Differences in the Conditions of Technological Progress in Europe}

\author{
Julianna Csugány \\ Eszterházy Károly University, Faculty of Economics and Social Sciences, \\ Institute of Economics, Eger, Hungary \\ csugany.julianna@uni-eszterhazy.hu

\section{Tamás Tánczos} \\ Eszterházy Károly University, Faculty of Economics and Social Sciences, \\ Institute of Economics, Eger, Hungary \\ tanczos.tamas@uni-eszterhazy.hu
}

\begin{abstract}
The spatial structure of the world is unequal, centres and peripheries alternate. There are significant social and development differences between countries in the world, but there is also an unequal development within the countries. The main purpose of the regional policy is to reduce spatial inequalities by catching up the underdeveloped areas. Nowadays, in the era of the Fourth Industrial Revolution, technological progress creates possibilities for developing regions to catch up, because new technologies require new skills that are less dependent on factor endowments of countries. Most economies are unable to create new technologies because they do not have the appropriate resources or their institutional environment does not favour innovation. However, technological progress can also be observed in these countries by adopting and applying new technologies effectively. This research aims to illustrate the regional differences in the conditions of technological progress in Europe, using multivariate statistical methods. Based on the European Regional Competitiveness Index, the research question to be analysed is whether new technologies may be able to decrease spatial differences. We compare the European regions in the field of innovation in order to highlight the critical areas that can promote or prevent the reduction of inequalities.
\end{abstract}

Keywords: regional differences in Europe, technological progress, innovation leaders, innovation followers

\section{Introduction}

There are significant differences in income and economic development between countries that can be derived from the spread of technology and the incentive system influencing this process. Diffusion is important for the realization of technological progress because it creates the possibility of imitation in countries where the capabilities do not allow the creation of new technologies. In developed countries, technological progress realizes in an innovation-driven way, where the invention is realized, but in most countries, the adoption of existing technologies, i.e. imitation, creates possibilities for technological and economic development. It
ORIGINAL SCIENTIFIC PAPER

RECEIVED: AU GUST 2019

REVISED: JANUARY 2020

ACCEPTED: FEBRUARY 2020

DOI: 10.2478/ngoe-2020-0001

UDK: 316.422.44:316.324:001.895(4)

JEL: 033, 057, R11

Citation: Csugány, J., \& Tánczos, T. (2020). Regional Differences in the Conditions of Technological Progress in Europe. Naše gospodarstvo/Our Economy, 66(1), 1-12. DOI: 10.2478/ ngoe-2020-0001

\section{NG OE}

\begin{tabular}{|c|c|c|}
\hline \multicolumn{3}{|c|}{$\begin{array}{l}\text { NAŠE GOSPODARSTVO } \\
\text { OUR ECONOMY }\end{array}$} \\
\hline Vol. 66 & No. 1 & 2020 \\
\hline
\end{tabular}


is also observed that countries are not homogeneous in terms of their level of development, there are significant regional differences not only in income but also in factor endowments which affect the possibilities of technology application.

Based on cross-sectional and panel data, national and regional growth rates are correlated with economic, social and political variables, including a number of factors influenced by government policies (Grossmann-Helpman, 1994, p. 23). Some empirical studies analyse the technological differences between countries, e.g. using the world technological frontier (see Caselli-Coleman, 2006; Growiec, 2006), but analysing regional competitiveness, the role of innovation is appreciated (Camagni-Capello, 2013; Békés, 2015). Our empirical research aims to highlight technological inequalities at a regional level. In the European Union, the NUTS classification (Nomenclature of territorial units for statistics) is used to collect regional statistics. Based on the NUTS system, the Regional Competitiveness Index (RCI) provides data to compare regions' performance in various areas of competitiveness. In this paper, we try to illustrate the regional differences in the conditions of technological progress in the European Union using various statistical methods.

\section{Why Is There a Technology Gap between Countries?}

Based on empirical experiences, differences in technology application across countries are closely related to income differences. The technology gap depends on how a country can mobilize its resources for the social, institutional and economic restructuring required by innovation, so close relationships can be assumed between a country's technological and economic development level (Fagerberg, 1987). Developed countries create new technology because their environment is favourable for this, but it is not certain that it will work in developing countries as well. The choice of the appropriate technology depends on factor-endowments, because technology can apply effectively if adequate resources are available. Each country chooses the best technology which fits its own capabilities, but it is not necessarily the best one in the world. Basu and Weil (1998, p. 1025) pointed out that a technology derived from a special combination of physical and human capital can be optimally matched to only one capital-labour ratio. This means that a given technology cannot work as efficiently as possible in every country. According to Krugman (1979), innovation is realized typically in developed countries, because human and physical resources, i.e. skills, knowledge and material resources required to create new ideas are available together, complemented by an appropriate institutional background. Barro and Sala-i-Martin (1997) pointed out that imitation, i.e. adoption of new technology, is cheaper in developing countries, where investment and appropriate human resources are required to apply new technologies. To reduce technological and economic inequalities between regions, the innovation policies may help lagging regions to reach a critical mass, which allows them to benefit from knowledge spillovers within and across the region (Autant-Bernard et al., 2013). Lukovics (2009) pointed out that the opportunities for improving competitiveness are scarce in several regions. Nevertheless, innovation can create possibilities for regions to converge.

\section{Database and Methodology}

Based on the NUTS classification, the Regional Competitiveness Index (RCI) measures the different dimensions of competitiveness at the regional level in the European Union. The RCI is published every three years, the latest database, the RCI 2019, contains data for the period 2015-2017. RCI defines the regional competitiveness as the ability of a region to offer an attractive and sustainable environment for firms and residents to live and work (Annoni - Dijkstra, 2019). For this purpose, the RCI is divided into 11 pillars including 74 indicators to measure the different aspects of regional competitiveness and classify them into three groups: Basic, Efficiency and Innovation. The Basic group represents the main drivers of competitiveness in all types of countries. The Efficiency group contains variables from the fields of labour market. The Innovation group consists of three pillars related to the relevant fields of innovation. The triple division is the basis for the weighting scheme whose starting point is that the higher the regional GDP per capita, the higher the weight assigned to innovative aspects. Because of this, RCI considers the region's stage of development, the RCI does not measure all regions with the same yardstick but focuses on the most relevant aspects given their level of development (Annoni - Dijkstra, 2019). The pillars of the groups can be seen in Figure 1.

Our research focuses on the Innovation group, with highlighted regional differences mainly in the innovation pillar because this pillar includes the most relevant variables related to technological progress. The regional technological readiness contains three variables at the regional level (households' access to broadband; individuals buying over internet; households' access to the internet). The business sophistication pillar measures the degree to which small and medium enterprises are involved in innovation cooperation, but there are very small differences in the most relevant variables. There are four variables in this pillar, employment and GVA (K-N sectors), innovative SMEs and 
Figure 1. The composition of the Regional Competitiveness Index (RCI)

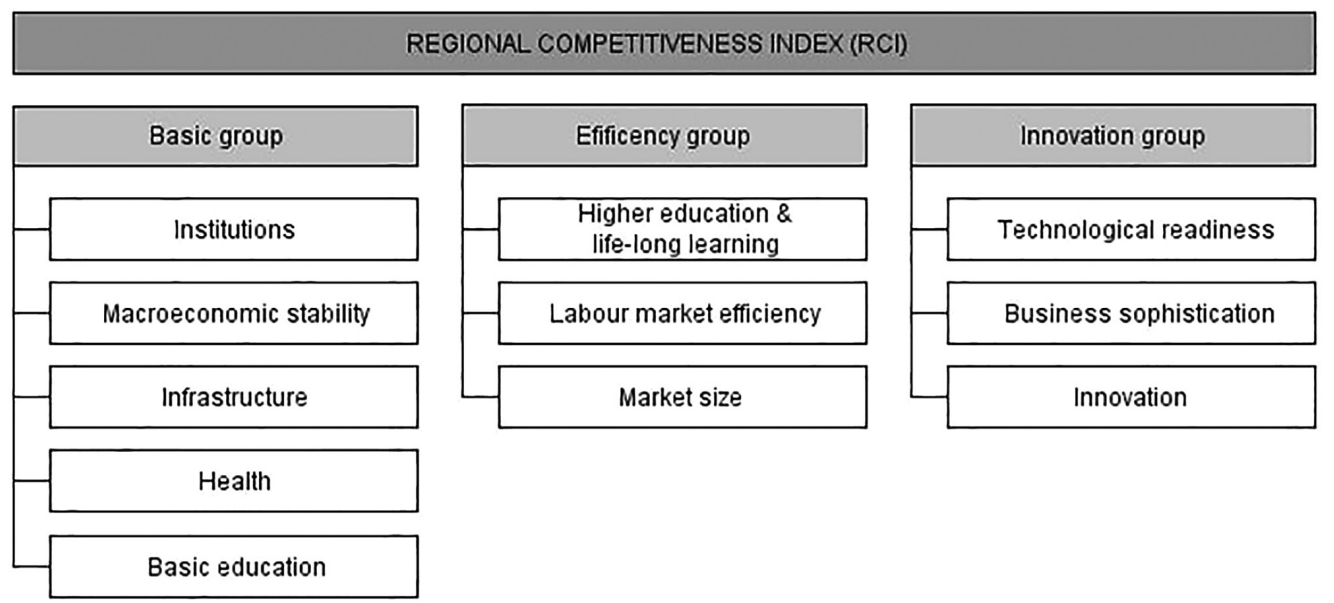

Source: Own construction based on Annoni and Dijkstra (2019)

marketing organisational innovators. The innovation pillar consists of eight variables by region, which characterize well the main fields of innovation as human resources, innovation output and corporate activities. The variables of innovation pillar are core creative class employment; knowledge workers; scientific publications; total intramural R\&D expenditure; human resources in Science and Technology; employment in technology and knowledge-intensive sectors; exports in medium-high/high tech manufacturing; sales of new-to-market and new-to-firm innovation. Compared to the previous RCI index, patenting activities are not measured at the regional level, but sales of new-to-market and new-to-firm innovation can be measured in regions.

To compare the European regions' performance, we used SPSS to analyse the differences using quantitative analytical techniques. Firstly, regions are grouped based on their economic performance, then we compare the means of innovation variables between performance groups. In the next step, we used cluster analysis to classify regions based on their innovation performance, and finally, the correlation analysis to analyse the relationship between economic and innovation indicators in order to highlight which innovation variables have the strongest effect on economic performance.

\section{Empirical Results}

There is a basic assumption in economics that the economic and technological performance are strongly correlated. Firstly, we categorized regions into five performance groups based on the GDP per capita, which reflects the stages of development. Figure 2 shows this classification, which follows the categorization of RCI. In the first stage of development, the regional GDP is below $50 \%$ of the EU-28 average. There are 16 regions, out of 268, in this group that can be defined as falling behind. In the second stage of development, including 67 regions, the regional GDP is at least $50 \%$, but less than $75 \%$ of the EU-28 average. These are the laggards where GDP per capita is less than three quarters of the EU-28 average. In the third stage of development,

Figure 2. The classification of 268 European regions based on their GDP per capita (average 2015-2017) related to EU28 $($ EU28 $=100 \%)$

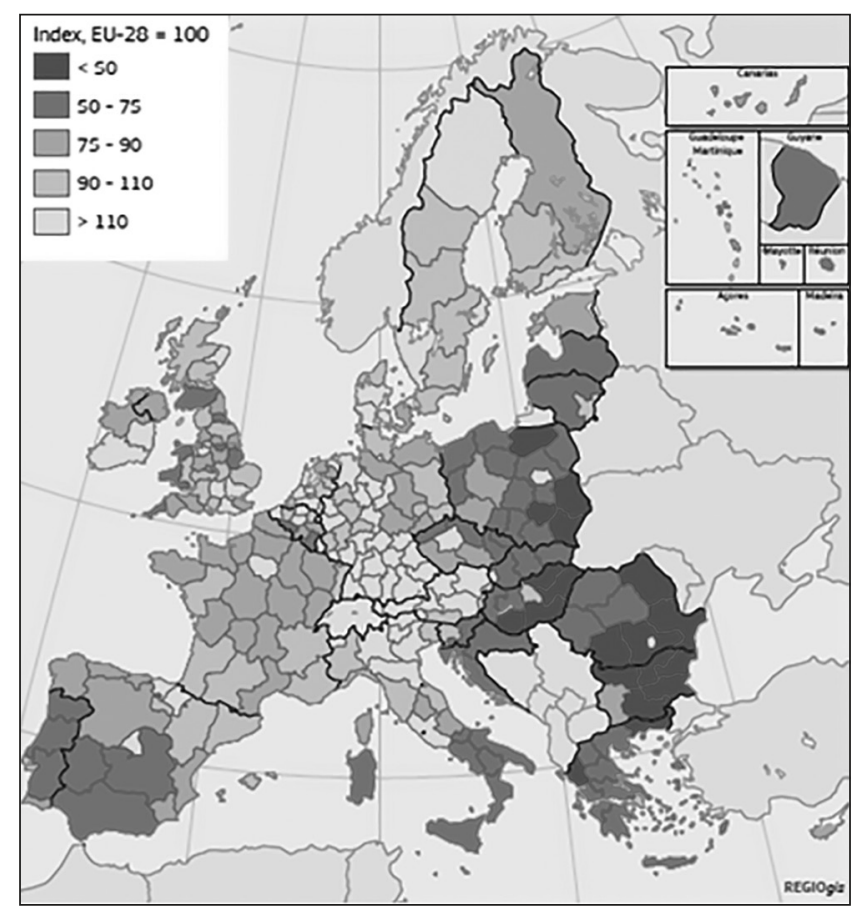

Source: Annoni and Dijkstra (2019, p.18) 
the regional GDP is at least $75 \%$, but less than $90 \%$ of the EU-28 average. These 55 regions can be called moderately developed. In the fourth stage of development, including 58 regions, the regional GDP is at least $90 \%$, but less than $110 \%$ of the EU-28 average. They can be called developed regions. In the fifth stage of development, the regional GDP is at least $110 \%$ of the EU-28 average. There are 72 regions, out of 268, in this group that are the most developed regions.

Based on the regional GDP per capita, there is one European region, i.e. Luxembourg, whose economic performance is prominently high, because in this country there is only one region. The best performing regions include the capitals of the countries, while the least performing regions are mostly in Hungary, Romania and Bulgaria.

Using the previous classification, we compare the innovation variables of regions' economic performance group. Table 1 contains the mean of innovation variables ${ }^{1}$ by regions' economic performance groups.

1 The description and the source of these variables are in Appendix (Table A1).
Using Kruskal-Wallis test to compare the means of economic performance groups, it can be stated that there is a significant difference between them. These results are found in the Appendix (Table A2). It is not surprising because, in general, the higher innovative activity is associated with the higher economic performance. Therefore, it is worth comparing the groups in pairs as well to highlight which factors can differentiate innovation performance between regions. Using Mann-Whitney U test to compare the means by pairs, it can be stated that there is no significant difference in employment in technology and knowledge-intensive sectors, marketing organizational innovators, innovative SMEs and exports in medium-high/ high tech manufacturing between the falling behind and laggards. There is a significant difference in all variables between the laggards and moderately developed regions. There is no significant difference in households' internet access, GVA (K-N sectors), innovative SMEs and sales of new-to-market and new-to-firm innovation between moderately developed and developed regions. The slightest differences are between the developed and most developed regions, because there is a significant difference only in households' internet access, marketing organizational innovators, innovative SMEs and exports in medium-high/

Table 1. Means of innovation variables by regions' economic performance groups

\begin{tabular}{|c|c|c|c|c|c|}
\hline Variables & $\begin{array}{l}\text { Falling } \\
\text { behind }\end{array}$ & Laggards & $\begin{array}{l}\text { Moderately } \\
\text { developed }\end{array}$ & Developed & $\begin{array}{l}\text { The most } \\
\text { developed }\end{array}$ \\
\hline Households' access to broadband (\% of total households) & 73.800 & 79.090 & 84.527 & 88.919 & 89.981 \\
\hline $\begin{array}{l}\text { Individuals buying over internet (\% of those who ordered } \\
\text { goods or services over the internet for private use) }\end{array}$ & 27.133 & 43.731 & 62.418 & 69.170 & 69.729 \\
\hline Households' internet access (\% of total households) & 75.000 & 81.045 & 87.564 & 91.463 & 92.335 \\
\hline Employment (K-N sectors*) (\% of total employment) & 6.861 & 9.849 & 14.440 & 16.201 & 17.874 \\
\hline GVA (K-N sectors) (\% of total GVA) & 16.682 & 19.120 & 23.417 & 24.990 & 26.305 \\
\hline Innovative SMEs (\% of total number of SMEs) & 0.123 & 0.288 & 0.443 & 0.505 & 0.428 \\
\hline Marketing organizational innovators (\% of total number of SMEs) & 0.139 & 0.279 & 0.402 & 0.444 & 0.479 \\
\hline Core creative class employment (\% of population aged $15-64$ ) & 6.038 & 7.268 & 8.871 & 11.290 & 12.397 \\
\hline Knowledge workers (\% out of total employment) & 25.826 & 31.646 & 38.000 & 42.617 & 44.842 \\
\hline Scientific publications (per million inhabitants) & 543.487 & 891.222 & 1346.186 & 2023.343 & 2480.317 \\
\hline Total intramural R\&D expenditure (\% of GDP) & 0.662 & 0.772 & 1.255 & 1.861 & 2.429 \\
\hline Human Resources in Science and Technology (\% of labour force) & 28.254 & 34.020 & 42.742 & 46.084 & 48.796 \\
\hline $\begin{array}{l}\text { Employment in technology and knowledge-intensive sectors } \\
\text { (\% of total employment) }\end{array}$ & 1.962 & 2.347 & 3.024 & 3.789 & 4.882 \\
\hline $\begin{array}{l}\text { Exports in medium-high/high tech manufacturing } \\
\text { (\% of total product exports) }\end{array}$ & 0.490 & 0.470 & 0.574 & 0.591 & 0.660 \\
\hline $\begin{array}{l}\text { Sales of new-to-market and new-to-firm innovation } \\
\text { (\% of turnover) }\end{array}$ & 0.242 & 0.362 & 0.463 & 0.461 & 0.413 \\
\hline
\end{tabular}

Source: own calculations based on RCI (2019)

* K-N sectors mean Financial and insurance activities; real estate activities; professional, scientific and technical activities; administrative and support service activities. 
high tech manufacturing. Based on these results, we can conclude that there is a break between the moderately developed and laggards, so the falling behind and laggards can be called innovation followers, while the other three economic performance groups, i.e. moderately developed, developed and most developed, can be called innovation leaders.

Cluster analysis is an adequate method to classify the regions based on their innovation performance. In the previous section, we compared the means, and the results show that there is no convincing difference in innovation variables between the developed and developing regions. Using a hierarchical cluster analysis, it can be stated that two clusters are optimal in this sample. This is confirmed by the previous empirical result, where there is a break between the moderately developed and laggards. In the K-means cluster analysis, there are 56 regions in cluster 1 , where all innovation variables are higher than in cluster 2 , consisting of 184 regions. 28 regions cannot be classified because of their missing data. Cluster 1 can be called innovation leaders, while cluster 2 are innovation followers. Table 2 shows the final cluster centres of innovation leader and follower groups. The cluster membership of the regions is found in the Appendix (Table A3).

Table 2. The final cluster centres of innovation leader and follower groups

\begin{tabular}{lrr} 
Variables & $\begin{array}{c}\text { Innovation } \\
\text { leaders }\end{array}$ & $\begin{array}{r}\text { Innovation } \\
\text { followers }\end{array}$ \\
\hline Households' access to broadband & 90.665 & 84.053 \\
\hline Individuals buying over internet & 72.864 & 56.893 \\
\hline Households' internet access & 92.614 & 86.632 \\
\hline Employment (K-N sectors) & 18.834 & 13.061 \\
\hline GVA (K-N sectors) (\% of total GVA) & 26.778 & 22.085 \\
\hline Innovative SMEs & 0.527 & 0.365 \\
\hline Marketing organizational innovators & 0.485 & 0.359 \\
\hline Core creative class employment & 13.230 & 8.902 \\
\hline Knowledge workers & 46.150 & 36.756 \\
\hline Scientific publications & 3350.058 & 1212.084 \\
\hline Total intramural R\&D expenditure & 2.560 & 1.334 \\
\hline $\begin{array}{l}\text { Human Resources in Science and } \\
\text { Technology }\end{array}$ & 50.076 & 40.195 \\
\hline $\begin{array}{l}\text { Employment in technology and } \\
\text { knowledge-intensive sectors }\end{array}$ & 4.813 & 3.076 \\
\hline $\begin{array}{l}\text { Exports in medium-high/high tech } \\
\text { manufacturing }\end{array}$ & 0.643 & 0.574 \\
\hline $\begin{array}{l}\text { Sales of new-to-market and } \\
\text { new-to-firm innovation }\end{array}$ & 0.428 & 0.416 \\
\hline
\end{tabular}

Source: Own calculations based on RCI (2019)
Table 3. Correlation coefficients between GDP per capita and innovation variables

\begin{tabular}{ll} 
Variables & $\begin{array}{c}\text { GDP per } \\
\text { capita }\end{array}$ \\
\hline Human Resources in Science and Technology & $0.694^{* *}$ \\
\hline Employment (K-N sectors) & $0.691^{* *}$ \\
\hline Knowledge workers & $0.685^{* *}$ \\
\hline Core creative class employment & $0.661^{* *}$ \\
\hline Employment in technology and knowledge- & $0.619^{* *}$ \\
\hline intensive sectors & $0.608^{* *}$ \\
\hline Households' internet access & $0.583^{* *}$ \\
\hline GVA (K-N sectors) (as \% of total GVA) & $0.559^{* *}$ \\
\hline Households' access to broadband & $0.553^{* *}$ \\
\hline Scientific publications & $0.543^{* *}$ \\
\hline Individuals buying over internet & $0.524^{* *}$ \\
\hline Marketing organizational innovators & $0.522^{* *}$ \\
\hline Total intramural R\&D expenditure & $0.395^{* *}$ \\
\hline Exports in medium-high/high tech manufacturing & $0.276^{* *}$ \\
\hline Innovative SMEs & $0.160^{*}$ \\
\hline Sales of new-to-market and new-to-firm innovation & \\
\hline * Correlation is significant at the 0.01 level (2-tailed) & \\
Source: Own calculations based on RCI (2019) & \\
\hline
\end{tabular}

The highest difference between innovation leaders and followers is in scientific publications, which is followed by total intramural R\&D expenditure and employment in technology and knowledge-intensive sectors. The slightest difference is in sales of new-to-market and new-to-firm innovation, which is followed by households' access to the internet and households' access to broadband. Based on these results, we can conclude that internet penetration is good in both groups, which creates possibilities to exploit the advantages of the new internet-based technologies.

There are some interesting cases where a low GDP per capita is associated with good innovation performance, while in contrast, there are cases where a high GDP per capita and low innovation performance can be seen. Because of this contrast, we ran a correlation analysis to reveal the relationship between innovation variables and economic performance of the regions. We found that there is a quite strong correlation between GDP per capita and innovation variables; the results can be seen in Table 3 .

Based on the correlation analysis, we can conclude that human resources in Science and Technology, employment (K-N sectors) and knowledge workers, meaning human resources indicators, have the biggest impact on innovation and economic performance of the regions. 


\section{Conclusion}

There are significant differences in income and economic development not only between countries, but also within the countries. These economic inequalities are strongly correlated with the innovation performance of the regions. In the era of the Fourth Industrial Revolution, technological progress creates possibilities for a catch-up, because new technologies require new skills that are less dependent on factor endowments of countries and regions. This research tried to illustrate the regional differences in the conditions of innovation in Europe using multivariate statistical methods. Based on the European Regional Competitiveness Index, the research question to be analysed is whether new technologies may be able to decrease spatial differences. To answer the question, we first classified the regions into five economic performance group based on RCI, i.e. the most developed, developed, moderately developed, laggards and falling behind, and then we compared 15 innovation variables in these groups. There is a significant difference in all variables between poor performing groups and a less significant difference between well performing ones. Our analysis confirmed a strong relationship between economic and innovation performance, but also highlighted a bigger difference between the regions in innovation than in economic performance. The critical area preventing the reduction of innovation inequalities is creation of new knowledge; if the region can develop its $R \& D \& I$ activity, it will become an innovation leader. It is promising that the regions converge in the field of human resources, which is the result of the labour market changes. Summarizing our results, we can conclude that regional differences remain in the era of the Fourth Industrial Revolution, but a restructuring of the economic process will occur in all regions regardless of whether the region is an innovation leader or follower, and technological progress will promote economic development.

\section{Acknowledgement}

Some parts of this paper have been presented at the 3rd International Scientific Conference - EMAN 2019.

\section{References}

Annoni, P., \& Dijkstra, L. (2019). The EU Regional Competitiveness Index 2019. Retrieved from https://ec.europa.eu/regional_policy/ sources/docgener/work/2019_03_rci2019.pdf

Camagni, R., \& Capello, R. (2013): Regional Competitiveness and Territorial Capital:A Conceptual Approach and Empirical Evidence from the European Union. Regional Studies, 47(9), 1383-1402. https://doi.org/10.1080/00343404.2012.681640

Corinne Autant-Bernard, C., Fadairo, M., \& Massard, N. (2013). Knowledge diffusion and innovation policies within the European regions: Challenges based on recent empirical evidence. Research Policy, 42(1), 196-210. https://doi.org/10.1016/j.respol.2012.07.009

Barro, R.J., \& Sala-i-Martin, X. (1997). Technological Diffusion, Convergence, and Growth.Journal of Economic Growth, 2(1), 1-26. https:// doi.org/10.1023/A:1009746629269

Basu, S., \& Weil, D. N. (1998). Appropriate Technology and Growth. The Quarterly Journal of Economics, 113(4), 1025 - 1054. https://doi. org/10.1162/003355398555829

Békés, G. (2015). Measuring regional competitiveness: A survey of approaches, measurement and data. Discussion Papers Institute of Economics, Centre for Economic and Regional Studies, Hungarian Academy of Sciences, Budapest.

Caselli, F., \& Coleman, W. J. (2006). The World Technology Frontier. The American Economic Review, 96(3), 499 - 522. https://doi. org/10.1257/aer.96.3.499

European Commission (2019). Regional Competitiveness Index. Retrieved from https://ec.europa.eu/regional_policy/en/information/ maps/regional_competitiveness/

Fagerberg, J. (1987). A Technology Gap Approach to Why Growth Rates Differ. Research Policy, 16, 87-99. https://doi.org/10.1016/00487333(87)90025-4

Grossmann, G. M., \& Helpman, E. (1994). Endogenous Innovation in the Theory of Growth. The Journal of Economic Perspectives, 8(1), 23-44. https://doi.org/10.1257/jep.8.1.23

Growiec, J. (2006). The World Technology Frontier: What Can We Learn from the US States? Oxford Bulletin of Economic and Statistics, 74(6), 777 - 807. https://doi.org/10.1111/j.1468-0084.2011.00686.x

Krugman, P. (1979). A Model of Innovation, Technology Transfer, and the World Distribution of Income. The Journal of Political Economy, 87(2), 253-266. https://doi.org/10.1086/260755

Lukovics, M. (2009). Measuring Regional Disparities on Competitiveness Basis. In Bajmócy, Z. - Lengyel, I. (eds): Regional Competitiveness, Innovation and Environment. JATEPress, Szeged, pp. 39 - 53.

Sleuwaegen. L., \& Ramboer, S. (2019). Regional competitiveness and high growth firms in the EU: the creativity premium. Applied Economics, https://doi.org/10.1080/00036846.2019.1686454 


\section{Appendix}

Table A1. The description and the source of innovation variables

\begin{tabular}{|c|c|c|}
\hline Variables & Description & Source \\
\hline Households' access to broadband & $\%$ of total households with access to broadband & Eurostat ICT Survey \\
\hline Individuals buying over internet & $\begin{array}{l}\% \text { of individuals who ordered goods or services over the } \\
\text { internet for private use }\end{array}$ & Eurostat ICT Survey \\
\hline Households' internet access & $\%$ of total households with internet access & Eurostat ICT Survey \\
\hline $\begin{array}{l}\text { Employment } \\
\text { (K-N sectors) }\end{array}$ & $\begin{array}{l}\text { Employment in the "Financial and insurance activities; } \\
\text { real estate activities; professional, scientific and technical } \\
\text { activities; administrative and support service activities" } \\
\text { sectors (K-N) as \% of total employment }\end{array}$ & Eurostat \\
\hline $\begin{array}{l}\text { GVA } \\
\text { (K-N sectors) }\end{array}$ & $\begin{array}{l}\text { GVA in the "Financial and insurance activities; real estate } \\
\text { activities; professional, scientific and technical activities; } \\
\text { administrative and support service activities" sectors (K-N) } \\
\text { as \% of total GVA }\end{array}$ & Eurostat \\
\hline Innovative SMEs & $\begin{array}{l}\text { SMEs with innovation co-operation activities as \% of total } \\
\text { number of SMEs }\end{array}$ & $\begin{array}{l}\text { I Regional Innovation } \\
\text { Scoreboard (RIS) }\end{array}$ \\
\hline Marketing organisational innovators & $\begin{array}{l}\text { SMEs introducing marketing or organisational innovation } \\
\text { as \% of total number of SMEs }\end{array}$ & $\begin{array}{l}\text { Regional Innovation } \\
\text { Scoreboard (RIS) }\end{array}$ \\
\hline Core creative class employment & $\%$ of population aged $15-64$ & Eurostat, LFS \\
\hline Knowledge workers & knowledge workers as \% of total employment & Eurostat, LFS \\
\hline Scientific publications & Scientific Publications per million inhabitants & $\begin{array}{l}\text { Centre for Science and } \\
\text { Technology Studies } \\
\text { (CWTS) - Leiden } \\
\text { University - based on } \\
\text { in-house version of Web } \\
\text { of Science }\end{array}$ \\
\hline Total intramural R\&D expenditure & total R\&D expenditure as \% of GDP & $\begin{array}{l}\text { Eurostat, Regional } \\
\text { Science and Technology } \\
\text { Statistics (RSTS) }\end{array}$ \\
\hline Human Resources in Science and Technology & $\begin{array}{l}\text { persons with higher education and/or employed in } \\
\text { Science and Technology as \% of labour force }\end{array}$ & Eurostat, RSTS \\
\hline $\begin{array}{l}\text { Employment in technology and knowledge- } \\
\text { intensive sectors }\end{array}$ & as $\%$ of total employment & Eurostat, RSTS \\
\hline $\begin{array}{l}\text { Exports in medium-high/high-tech } \\
\text { manufacturing }\end{array}$ & $\begin{array}{l}\text { Exports in medium/high technology products as \% } \\
\text { of total product exports: measures the technological } \\
\text { competitiveness of the EU, the ability to commercialise } \\
\text { the results of research and development (R\&D) }\end{array}$ & $\begin{array}{l}\text { Regional Innovation } \\
\text { Scoreboard 2017, EC-DG } \\
\text { GROW }\end{array}$ \\
\hline $\begin{array}{l}\text { Sales of new-to-market and new-to-firm } \\
\text { innovation }\end{array}$ & $\begin{array}{l}\text { Sales of new-to-market and new-to-firm innovations as } \\
\% \text { of turnover: it captures both the creation of state-of- } \\
\text { the-art technologies (new to market products) and the } \\
\text { diffusion of these technologies (new to firm products) }\end{array}$ & $\begin{array}{l}\text { Regional Innovation } \\
\text { Scoreboard 2017, EC-DG } \\
\text { GROW }\end{array}$ \\
\hline
\end{tabular}

Source: RCI (2019) 
Table A2. The results of Kruskal-Wallis test

\begin{tabular}{lcc} 
Variables & Chi-Square & Asymp. Sig. \\
\hline Human Resources in Science and Technology & 132.534 & 0.000 \\
\hline Employment (K-N sectors) & 123.183 & 0.000 \\
\hline Knowledge workers & 127.245 & 0.000 \\
\hline Core creative class employment & 128.630 & 0.000 \\
\hline Employment in technology and knowledge-intensive sectors & 83.976 & 0.000 \\
\hline Households' internet access & 121.357 & 0.000 \\
\hline GVA (K-N sectors) (as \% of total GVA) & 81.576 & 0.000 \\
\hline Households' access to broadband & 100.339 & 0.000 \\
\hline Scientific publications & 97.194 & 0.000 \\
\hline Individuals buying over internet & 102.652 & 0.000 \\
\hline Marketing organizational innovators & 71.967 & 0.000 \\
\hline Total intramural R\&D expenditure & 113.802 & 0.000 \\
\hline Exports in medium-high/high tech manufacturing & 27.595 & 0.000 \\
\hline Innovative SMEs & 55.971 & 0.000 \\
\hline Sales of new-to-market and new-to-firm innovation & 41.721 & 0.000 \\
\hline
\end{tabular}

Source: Own calculations based on RCI (2019).

Table A2. The results of Mann-Whitney $U$ tests

\begin{tabular}{|c|c|c|c|c|c|c|c|c|}
\hline \multirow{3}{*}{$\begin{array}{l}\text { Variables } \\
\text { Human Resources in Science and Technology }\end{array}$} & \multicolumn{8}{|c|}{ Mann-Whitney U and Sig. } \\
\hline & \multicolumn{2}{|c|}{$\begin{array}{c}\text { Falling } \\
\text { behind - laggards }\end{array}$} & \multicolumn{2}{|c|}{$\begin{array}{l}\text { Laggards - } \\
\text { moderate developed }\end{array}$} & \multicolumn{2}{|c|}{$\begin{array}{c}\text { Moderate } \\
\text { developed - } \\
\text { developed }\end{array}$} & \multicolumn{2}{|c|}{$\begin{array}{l}\text { Developed - the } \\
\text { most developed }\end{array}$} \\
\hline & 275.500 & 0.006 & 1132.0 & 0.000 & 1051.0 & 0.002 & 1860.5 & 0.346 \\
\hline Employment (K-N sectors) & 188.000 & 0.000 & 749.5 & 0.000 & 1197.0 & 0.022 & 2002.0 & 0.787 \\
\hline Knowledge workers & 243.000 & 0.002 & 895.5 & 0.000 & 996.5 & 0.001 & 1802.5 & 0.223 \\
\hline Core creative class employment & 205.000 & 0.000 & 541.0 & 0.000 & 1174.0 & 0.016 & 1741.0 & 0.104 \\
\hline $\begin{array}{l}\text { Employment in technology and knowledge- } \\
\text { intensive sectors }\end{array}$ & 387.000 & 0.085 & 930.0 & 0.000 & 1240.0 & 0.041 & 1896.0 & 0.369 \\
\hline Households' internet access & 221.000 & 0.002 & 929.0 & 0.000 & 1230.0 & 0.126 & 1543.0 & 0.038 \\
\hline $\begin{array}{l}\text { GVA (K-N sectors) } \\
\text { (as \% of total GVA) }\end{array}$ & 277.000 & 0.022 & 909.0 & 0.000 & 1166.0 & 0.055 & 1676.0 & 0.154 \\
\hline Households' access to broadband & 279.000 & 0.009 & 981.0 & 0.000 & 797.0 & 0.000 & 1760.0 & 0.124 \\
\hline Scientific publications & 232.000 & 0.001 & 834.0 & 0.000 & 896.0 & 0.000 & 1816.0 & 0.203 \\
\hline Individuals buying over internet & 289.000 & 0.017 & 953.0 & 0.000 & 897.0 & 0.000 & 1722.5 & 0.087 \\
\hline Marketing organizational innovators & 394.000 & 0.282 & 906.0 & 0.000 & 975.0 & 0.001 & 1542.0 & 0.011 \\
\hline Total intramural R\&D expenditure & 267.500 & 0.002 & 599.0 & 0.000 & 1056.0 & 0.002 & 1724.5 & 0.089 \\
\hline $\begin{array}{l}\text { Exports in medium-high/high tech } \\
\text { manufacturing }\end{array}$ & 300.000 & 0.113 & 1034.0 & 0.002 & 944.0 & 0.001 & 1473.0 & 0.011 \\
\hline Innovative SMEs & 433.000 & 0.822 & 1086.0 & 0.006 & 1397.0 & 0.717 & 1437.0 & 0.019 \\
\hline $\begin{array}{l}\text { Sales of new-to-market and new-to-firm } \\
\text { innovation }\end{array}$ & 266.000 & 0.015 & 1068.0 & 0.004 & 1457.0 & 0.879 & 1613.0 & 0.083 \\
\hline
\end{tabular}

Source: Own calculations based on RCI (2019). 
Table A3. The members of the innovation follower cluster

\begin{tabular}{|c|c|}
\hline Region & Distance \\
\hline Kärnten & 657.190 \\
\hline Steiermark & 657.207 \\
\hline Oberösterreich & 197.391 \\
\hline Salzburg & 197.530 \\
\hline Tirol & 197.460 \\
\hline Vorarlberg & 197.527 \\
\hline $\begin{array}{l}\text { Rég. de Bruxelles-Cap./Brussels Hfst. Gew. \& } \\
\text { Vlaams-Brabant \& Brabant Wallon }\end{array}$ & 960.966 \\
\hline Hainaut & 77.906 \\
\hline Liège & 78.259 \\
\hline Luxembourg & 77.683 \\
\hline Namur & 78.801 \\
\hline Severozapaden & 1138.700 \\
\hline Severen tsentralen & 1138.714 \\
\hline Severoiztochen & 1138.253 \\
\hline Yugoiztochen & 1138.678 \\
\hline Yugozapaden & 584.004 \\
\hline Yuzhen tsentralen & 584.763 \\
\hline Jihozápad & 114.289 \\
\hline Severozápad & 1056.089 \\
\hline Severovýchod & 528.990 \\
\hline Jihovýchod & 609.922 \\
\hline Střední Morava & 83.648 \\
\hline Moravskoslezsko & 600.530 \\
\hline Stuttgart & 295.997 \\
\hline Freiburg & 983.999 \\
\hline Niederbayern & 934.843 \\
\hline Oberpfalz & 363.938 \\
\hline Oberfranken & 56.335 \\
\hline Mittelfranken & 1024.025 \\
\hline Unterfranken & 773.620 \\
\hline Schwaben & 803.886 \\
\hline Darmstadt & 567.637 \\
\hline Kassel & 628.712 \\
\hline Mecklenburg-Vorpommern & 660.800 \\
\hline Hannover & 740.291 \\
\hline Lüneburg & 968.643 \\
\hline Weser-Ems & 577.299 \\
\hline Düsseldorf & 29.414 \\
\hline Münster & 26.494 \\
\hline Detmold & 380.936 \\
\hline Auvergne & 760.655 \\
\hline Rhône-Alpes & 684.313 \\
\hline Chemnitz & 450.343 \\
\hline
\end{tabular}

\begin{tabular}{|c|c|}
\hline Region & Distance \\
\hline Provence-Alpes-Côte d’Azur & 476.881 \\
\hline Corse & 413.365 \\
\hline Jadranska Hrvatska & 475.030 \\
\hline Kontinentalna Hrvatska & 138.323 \\
\hline Közép-Magyarország & 466.260 \\
\hline Közép-Dunántúl & 893.377 \\
\hline Nyugat-Dunántúl & 962.231 \\
\hline Dél-Dunántúl & 527.862 \\
\hline Észak-Magyarország & 1058.599 \\
\hline Észak-Alföld & 449.588 \\
\hline Dél-Alföld & 307.640 \\
\hline Northern and Western & 222.451 \\
\hline Southern & 988.086 \\
\hline Eastern and Midland & 729.436 \\
\hline Piemonte & 182.733 \\
\hline Liguria & 905.452 \\
\hline Lombardia & 476.141 \\
\hline Abruzzo & 432.287 \\
\hline Molise & 575.496 \\
\hline Campania & 61.229 \\
\hline Puglia & 196.686 \\
\hline Basilicata & 54.608 \\
\hline Calabria & 277.668 \\
\hline Sicilia & 171.569 \\
\hline Sardegna & 81.205 \\
\hline Prov. Autonoma di Bolzano/Bozen & 250.693 \\
\hline Veneto & 311.138 \\
\hline Emilia-Romagna & 967.655 \\
\hline Umbria & 972.166 \\
\hline Marche & 46.345 \\
\hline Friesland & 789.293 \\
\hline Drenthe & 603.403 \\
\hline Overijssel & 691.864 \\
\hline Zeeland & 774.430 \\
\hline Noord-Brabant & 280.041 \\
\hline Małopolskie & 441.202 \\
\hline Śląskie & 569.732 \\
\hline Wielkopolskie & 309.420 \\
\hline Zachodniopomorskie & 667.886 \\
\hline Arnsberg & 41.706 \\
\hline Koblenz & 977.566 \\
\hline Saarland & 544.879 \\
\hline Kujawsko-pomorskie & 650.085 \\
\hline
\end{tabular}


Table A3. The members of the innovation follower cluster (continue)

\begin{tabular}{|c|c|c|c|}
\hline Region & Distance & Region & Distance \\
\hline Sachsen-Anhalt & 251.977 & Warmińsko-mazurskie & 645.317 \\
\hline Schleswig-Holstein & 248.971 & Pomorskie & 338.752 \\
\hline Thüringen & 503.436 & Łódzkie & 301.078 \\
\hline Sjælland & 571.209 & Lubelskie & 280.820 \\
\hline Attiki & 344.722 & Podkarpackie & 914.990 \\
\hline Kriti & 847.632 & Podlaskie & 522.166 \\
\hline Anatoliki Makedonia, Thraki & 529.543 & Warszawski stołeczny & 310.703 \\
\hline Kentriki Makedonia & 116.366 & Mazowiecki regionalny & 369.935 \\
\hline Thessalia & 392.732 & Norte & 349.270 \\
\hline Dytiki Ellada & 480.590 & Centro & 615.429 \\
\hline Sterea Ellada & 1073.428 & Alentejo & 598.729 \\
\hline Peloponnisos & 1058.698 & Nord-Vest & 498.507 \\
\hline Galicia & 179.461 & Sud - Muntenia & 1147.642 \\
\hline Principado de Asturias & 476.347 & Bucureşti - Ilfov & 444.442 \\
\hline Cantabria & 644.102 & Sud-Vest Oltenia & 1030.273 \\
\hline País Vasco & 687.921 & Vest & 680.140 \\
\hline La Rioja & 100.516 & Småland med öarna & 332.533 \\
\hline Aragón & 760.932 & Norra Mellansverige & 436.671 \\
\hline Castilla y León & 15.556 & Mellersta Norrland & 477.829 \\
\hline Castilla-La Mancha & 482.977 & Vzhodna Slovenija & 513.351 \\
\hline Extremadura & 405.620 & Západné Slovensko & 967.062 \\
\hline Cataluña & 1057.064 & Stredné Slovensko & 842.214 \\
\hline Comunidad Valenciana & 328.561 & Východné Slovensko & 508.412 \\
\hline Illes Balears & 256.044 & Tees Valley and Durham & 974.680 \\
\hline Andalucía & 16.700 & Northumberland and Tyne and Wear & 974.713 \\
\hline Región de Murcia & 202.477 & Cumbria & 702.086 \\
\hline Canarias & 277.380 & Greater Manchester & 702.349 \\
\hline$\underline{\text { Länsi-Suomi }}$ & 980.785 & $\underline{\text { Lancashire }}$ & 702.134 \\
\hline Centre - Val de Loire & 504.079 & Cheshire & 702.619 \\
\hline Bourgogne & 494.609 & Merseyside & 702.219 \\
\hline Franche-Comté & 142.805 & East Yorkshire and Northern Lincolnshire & 832.831 \\
\hline Basse-Normandie & 497.923 & North Yorkshire & 833.037 \\
\hline Haute-Normandie & 504.429 & South Yorkshire & 832.869 \\
\hline Nord-Pas de Calais & 209.396 & West Yorkshire & 832.990 \\
\hline Picardie & 501.252 & Derbyshire and Nottinghamshire & 512.501 \\
\hline Alsace & 127.256 & Lincolnshire & 512.320 \\
\hline Champagne-Ardenne & 494.595 & Leicestershire, Rutland and Northamptonshire & 512.532 \\
\hline Lorraine & 158.712 & Aquitaine & 269.026 \\
\hline Pays de la Loire & 164.606 & Gloucestershire, Wiltshire and Bristol/Bath area & 728.084 \\
\hline Bretagne & 150.464 & Poitou-Charentes & 136.013 \\
\hline Lubuskie & 963.683 & Languedoc-Roussillon & 425.155 \\
\hline Dolnośląskie & 100.542 & Midi-Pyrénées & 271.783 \\
\hline Opolskie & 867.555 & Devon & 727.731 \\
\hline West Wales and The Valleys & 539.182 & West Midlands & 371.869 \\
\hline
\end{tabular}


Table A3. The members of the innovation follower cluster (continue)

\begin{tabular}{|c|c|c|c|}
\hline Region & Distance & Region & Distance \\
\hline East Wales & 539.449 & Limousin & 355.290 \\
\hline Northern Ireland & 266.230 & Dorset and Somerset & 727.801 \\
\hline Shropshire and Staffordshire & 371.756 & Cornwall and Isles of Scilly & 727.688 \\
\hline Herefordshire, Worcestershire and Warwickshire & 372.152 & Gloucestershire, Wiltshire and Bristol/Bath area & 728.084 \\
\hline
\end{tabular}

Table A3. The members of the innovation leader cluster

\begin{tabular}{|c|c|c|c|}
\hline Region & Distance & Region & Distance \\
\hline Wien \& Niederösterreich & 556.399 & Lazio & 869.280 \\
\hline Burgenland & 771.326 & Flevoland \& Noord-Holland & 478.322 \\
\hline Antwerpen & 930.443 & Groningen & 4853.869 \\
\hline Limburg (BE) & 930.431 & Gelderland & 557.876 \\
\hline Oost-Vlaanderen & 930.432 & Utrecht & 3053.473 \\
\hline West-Vlaanderen & 930.526 & Zuid-Holland & 231.477 \\
\hline Praha \& Střední Čechy & 260.420 & Limburg (NL) & 213.032 \\
\hline Berlin \& Branderburg & 446.700 & Área Metr. de Lisboa & 1002.969 \\
\hline Karlsruhe & 696.410 & Stockholm & 1736.441 \\
\hline Tübingen & 180.505 & Östra Mellansverige & 1600.483 \\
\hline Oberbayern & 179.705 & Sydsverige & 312.084 \\
\hline Bremen & 191.190 & Västsverige & 531.674 \\
\hline Hamburg & 107.031 & Övre Norrland & 2104.937 \\
\hline Gießen & 38.656 & Zahodna Slovenija & 330.830 \\
\hline Braunschweig & 395.195 & Bratislavský kraj & 184.773 \\
\hline Köln & 422.771 & $\begin{array}{l}\text { Inner London West \& Inner London East \& Outer } \\
\text { London East-North-East \& Outer London South \& } \\
\text { Outer London West North West \& Bedfordshire/ } \\
\text { Hertfordshire \& Essex }\end{array}$ & 432.815 \\
\hline Rheinhessen-Pfalz & 955.970 & East Anglia & 705.233 \\
\hline Dresden & 246.550 & Berkshire, Buckinghamshire and Oxfordshire & 517.716 \\
\hline Leipzig & 325.820 & Surrey, East and West Sussex & 517.649 \\
\hline Hovedstaden & 3368.177 & Hampshire and Isle of Wight & 517.394 \\
\hline Syddanmark & 1020.458 & Kent & 517.389 \\
\hline Midtjylland & 378.766 & North Eastern Scotland & 449.858 \\
\hline Nordjylland & 235.465 & Highlands and Islands & 371.050 \\
\hline Comunidad Foral de Navarra & 971.849 & Eastern Scotland & 447.686 \\
\hline Comunidad de Madrid & 679.761 & West Central Scotland & 409.492 \\
\hline Pohjois- ja Itä-Suomi & 931.650 & & \\
\hline Île de France & 603.479 & & \\
\hline Provincia Autonoma di Trento & 238.680 & & \\
\hline Friuli-Venezia Giulia & 262.070 & & \\
\hline Toscana & 859.977 & & \\
\hline Southern Scotland & 304.874 & & \\
\hline
\end{tabular}

Note: There is no cluster membership because of the missing data for: Kýpros; Trier; Eesti; Voreio Aigaio; Notio Aigaio; Dytiki Makedonia; Ipeiros; Ionia Nisia; Ciudad Autónoma de Ceuta; Ciudad Autónoma de Melilla; Helsinki-Uusimaa; Etelä-Suomi; Åland; Guadeloupe; Martinique; Guyane; La Réunion; Mayotte; Valle d'Aosta/Vallée d'Aoste; Sostinės regionas; Vidurio ir vakarų Lietuvos regionas; Luxembourg; Latvija; Malta; Świętokrzyskie; Algarve; Região Autónoma dos Açores; Região Autónoma da Madeira. 


\section{Regionalne razlike $v$ pogojih tehnološkega napredka v Evropi}

\section{Izvleček}

Prostorska struktura sveta je neenakomerna, središča in obrobja se izmenjavajo. Obstajajo znatne družbene in razvojne razlike med državami v svetu ter tudi neenakomeren razvoj znotraj držav. Ključni namen regionalne politike je zmanjšati prostorske neenakosti med razvitimi in nerazvitimi območji. Danes, v obdobju četrte industrijske revolucije, tehnološki napredek ustvarja možnosti, da regije v razvoju nadoknadijo zaostanek, ker nove tehnologije zahtevajo nove veščine, ki so manj odvisne od posedovanja faktorjev držav. Večina gospodarstev je nezmožnih ustvarjati nove tehnologije, ker nimajo primernih virov ali njihovo institucionalno okolje ni naklonjeno novostim. Kljub temu pa je v teh državah s sprejemanjem in učinkovito uporabo novih tehnologij mogoče spremljati tehnološki razvoj. Cilj te raziskave je ponazoriti regionalne razlike v pogojih tehnološkega napredka v Evropi z uporabo multivariatnih statističnih metod. Temelječa na Indeksu evropske regionalne konkurenčnosti, poskuša odgovoriti na raziskovalno vprašanje, ali so nove tehnologije zmožne zmanjšati prostorske razlike. Primerjamo evropske regije na področju inoviranja, da bi izpostavili kritična področja, ki lahko spodbudijo ali preprečijo zmanjšanje neenakosti.

Ključne besede: regionalne razlike v Evropi, tehnološki napredek, inovacijski vodje, inovacijski sledilci 